9 Bosh J, Yusuf S, Pogue J, Sleight P, Lonn E, Rangoonwala B, et al. Use of ramipril in preventing stroke: double blind randomised trial. $B M$ ramipril in preve

10 Marre M, Hallab M, Billiard A, Le Jeune JJ, Bled F, Girault A, et al. Small doses of ramipril to reduce microalbuminuria in diabetic patients with incipient nephropathy independently of blood pressure changes. J Cardiovasc Pharmacol 1991;18:S165-8.

11 Lievre M, Gueret P, Gayet C, Roudaut R, Haugh MC, Delair S, et al. Ramipril-induced regression of left ventricular hypertrophy in treated hypertensive individual. HYCAR Study Group. Hypertension 1995;25:92-7.

12 Lievre M, Marre M, Chatellier G, Plouin P, Reglier J, Richardson L, et al. The non-insulin-dependent diabetes, hypertension, microalbuminuria or design, organization, and patient recruitment. DIABHYCAR Study Group. Control Clin Trials 2000;21:383-96.

3 Chobanian AV, Hope S, Brecher P. Dissociation between the antiathero- sclerotic effect of trandolapril and suppression of serum and aorticangiotensin-converting enzyme activity in the Watanabe heritable hyperlipidemic rabbit. Hypertension 1995;25:1306-10.

14 Lonn EM, Yusuf S, Dzavik V, Doris I, Yi Q, Smith S, et al, for the SECURE Investigators. Effects of ramipril and vitamin $\mathrm{E}$ on atherosclerosis: the study to evaluate carotid ultrasound changes in patients treated with ramipril and vitamin E. Circulation 2001;103:919-25.

15 Parving HH, Lehnert H, Bröchner-Mortensen J, Goms R, Andersen S, Arner $P$, for the Irbesartan in Patients Type 2 Diabetes And Microalbumin ment of dabetic nephropaty in patientwi Med 2001;345:870-8.

16 Maillard MP, Wurzner G, Nussberger J, Centeno C, Burnier M, Brunner HR. Comparative angiotensin II receptor blockade in healthy volunteers: the importance of dosing. Clin Pharmacol Ther 2002;71:68-76.

doi $10.1136 /$ bmj.37970.629537.0D

\title{
"Drink plenty of fluids": a systematic review of evidence for this recommendation in acute respiratory infections
}

\author{
Michelle P B Guppy, Sharon M Mickan, Chris B Del Mar
}

Doctors often recommend drinking extra fluids to patients with respiratory infections. Theoretical benefits for this advice are replacing insensible fluid losses from fever and respiratory tract evaporation, correcting dehydration from reduced intake, and reducing the viscosity of mucus. ${ }^{12}$ To many this advice is self evident and justified on the basis that even if the benefit is uncertain, or at best small, at least it is harmless.

However, there are theoretical reasons for increased fluid intake to cause harm. Antidiuretic hormone conserves fluid by stimulating water reabsorption from the renal collecting ducts. Increased antidiuretic hormone secretion has been reported in adults and children with lower respiratory tract infections of bronchitis, bronchiolitis, and pneumonia of viral and bacterial aetiology. ${ }^{3}$ It is uncertain if this also occurs in upper respiratory tract infections.

Several mechanisms have been proposed for this increased hormone secretion, acting through fever, hypoxia, hypercarbia, pain, emotion, or nausea. Secretion may be stimulated by a resetting of osmostat receptors to lower levels. ${ }^{3}$ Also, lung hyperinflation and pulmonary infiltrates may stimulate hormone secretion by causing a false perception of hypovolaemia by intrathoracic receptors. ${ }^{4}$ This would be in keeping with findings that antidiuretic hormone secretion in pneumonia increases proportionally with the extent of lung parenchymal involvement. ${ }^{3}$

Giving extra fluids while antidiuretic hormone secretion is increased may theoretically lead to hyponatraemia and fluid overload. Clinical symptoms of hyponatraemia are irritability, confusion, lethargy, coma, and convulsions. Fluid restriction may be appropriate management to prevent this.

\section{Methods and results}

To determine whether recommending increased fluids was beneficial or harmful, we undertook a systematic review and posed three questions:

Does recommending increased fluid intake for acute respiratory infections improve duration and severity of symptoms?

Are there adverse effects from this recommendation? Are any benefits or harm related to site (upper or lower respiratory tract) or severity of illness?

Using the Cochrane Acute Respiratory Infections Group search strategy, together with additional terms (see bmj.com for details), we did a conventional search of the Cochrane Central Register of Controlled Trials, Medline (1966-2003), Embase (1974-2003), and Current Contents (1966-2003). We examined references of relevant papers and contacted experts in the subject.

We found no randomised controlled trials comparing increased and restricted fluid regimens in patients with respiratory infections. Two prospective prevalence studies reported hyponatraemia at rates of $31 \%$ and $45 \%$ for children with moderate to severe pneumonia

Extra details about the search strategy used and tables detailing results from other studies appear on bmj.com
Centre for General Practice, Medical School, University of Queensland, Herston, 4006 Oueensland, Australia

Michelle P B Guppy academic general practice registrar Sharon M Mickan senior research fellow

Chris B Del Mar professor of general practice

Correspondence to: C B Del Mar c.delmar@cgp. uq.edu.au

BMJ 2004;328:499-500

Studies showing hyponatraemia in non-dehydrated patients with respiratory infections

\begin{tabular}{|c|c|c|c|c|c|c|c|}
\hline Study & $\begin{array}{l}\text { No of } \\
\text { patients }\end{array}$ & Age & Diagnosis & Exclusions & $\begin{array}{c}\text { Serum sodium level } \\
(\mathrm{mmol} / \mathrm{l})\end{array}$ & Serum or urine osmolality & $\begin{array}{l}\text { Symptoms associated with } \\
\text { low sodium level }\end{array}$ \\
\hline $\begin{array}{l}\text { Dhawan et al } \\
1992^{2}\end{array}$ & 100 & 1 month-12 years & Pneumonia & Clinical dehydration & $\begin{array}{l}31 \text { patients } \\
\text { had } \mathrm{Na}<130\end{array}$ & $\begin{array}{c}\text { Serum dilute in 29, } \\
\text { concentrated in } 2 \text { (probable } \\
\text { dehydration) }\end{array}$ & 4 died, $\mathrm{Na}<125 \mathrm{mmol} / \mathrm{l}$ \\
\hline $\begin{array}{l}\text { Shann et al } \\
1985^{1}\end{array}$ & 73 & $\geq 1$ month & Pneumonia & Clinical dehydration & $\begin{array}{l}33 \text { patients had } \\
\mathrm{Na}<134\end{array}$ & - & $\begin{array}{c}\text { Hyponatraemia } 2-3 \text { times } \\
\text { more frequent with severe } \\
\text { pneumonia }\end{array}$ \\
\hline $\begin{array}{c}\text { Rivers et al } \\
1981^{5}\end{array}$ & 4 & $6-8$ weeks and 6 months & $\begin{array}{c}3 \text { bronchiolitis, } \\
1 \text { pneumonia }\end{array}$ & - & $\begin{array}{l}3 \text { patients had } \\
\text { Na 114-124 }\end{array}$ & $\begin{array}{l}\text { Concentrated urine, or not } \\
\text { maximally dilute urine }\end{array}$ & $\begin{array}{l}\text { Seizures in one patient with } \\
\text { bronchiolitis }\end{array}$ \\
\hline
\end{tabular}


(see table). ${ }^{12}$ None of these children showed clinical signs of dehydration. Symptoms associated with hyponatraemia were not reported, but four children with a serum sodium below $125 \mathrm{mmol} / \mathrm{l}$ died during one study.

We also found several case series in which patients with respiratory infections developed hyponatraemia, of which some were symptomatic (table). ${ }^{5}$ These patients were all successfully treated with fluid restriction.

\section{Comment}

We found data to suggest that giving increased fluids to patients with respiratory infections may cause harm. To date there are no randomised controlled trials to provide definitive evidence, and these need to be done. Until we have this evidence, we should be cautious about universally recommending increased fluids to patients, especially those with infections of the lower respiratory tract.
We thank Ruth Foxlee, Cochrane Acute Respiratory Infections Group Trials Search Coordinator, for performing the searches. Contributors: CBDM conceived and supervised the study, and prepared the manuscript. MPBG and SMM undertook the search, and contributed to writing the manuscript. CBDM is the guarantor for the study.

Funding: The post of academic research registrar is funded by General Practice Education and Training.

Competing interests: None declared.

1 Shann F, Germer S. Hyponatraemia associated with pneumonia or bacterial meningitis. Arch Dis Child 1985;60:963-6.

Dhawan A, Narang A, Singhi S. Hyponatraemia and the inappropriate ADH syndrome in pneumonia. Ann Trop Paediatr 1992;12:455-62.

3 Dreyfuss D, Leviel F, Paillard M, Rahmani J, Coste F. Acute infectious pneumonia is accompanied by latent vasopressin-dependent impair ment of renal water excretion. Am Rev Respir Dis 1988;138:583-9.

4 Gozal D, Colin AA, Jaffe M, Hochberg Z. Water, electrolyte, and endocrine homeostasis in infants with bronchiolitis. Pediatr Res 1990;27:204-9.

Rivers RP, Forsling ML, Olver RP. Inappropriate secretion of antidiuretic hormone in infants with respiratory infections. Arch Dis Child 1981;56:358-63.

doi 10.1136/bmj.38028.627593.BE

\title{
Effect of statin treatment for familial hypercholesterolaemia on life assurance: results of consecutive surveys in 1990 and 2002
}

\author{
H A W Neil, T Hammond, D Mant, S E Humphries Topic: 183;163
}

Oxford Centre for Diabetes,

Endocrinology and Metabolism,

Churchill Hospital,

Oxford OX3 7HJ

H A W Neil

honorary consultant

physician

Division of Public

Health and Primary

Health Care

Institute of Health

Sciences, University

of Oxford, Oxford

OX3 7LF

T Hammond

research assistant

D Mant

professor of general

practice

Centre for

Cardiovascular

Genetics, British

Heart Foundation

Laboratories, Royal

Free and University

College London

Medical School,

London WC1E 6JJ

S E Humphries

professor of

cardioriascular

genetics

Correspondence to:

H A W Neil

andrew.neil@

wolfson.ox.ac.uk

BMJ 2004;328:500-1
One of the concerns often raised about genetic testing is the possibility that a positive result (or even disclosing that the test has been taken) may result in difficulty in obtaining life assurance. Currently the UK insurance industry has declared a moratorium on requiring genetic tests from applicants, ${ }^{1}$ but since DNA based tests offer a definitive, highly specific diagnosis they are likely eventually to replace less specific clinical diagnostic criteria for many inherited disorders. Early, presymptomatic treatment may increase life expectancy by preventing or reducing the risk of developing the disease or associated complications. However, if life assurance policy premiums do not adequately reflect the reduction in mortality with treatment relatives of affected probands may be deterred from being tested. We examined how life assurance companies have responded to the improvement in the prognosis of heterozygous familial hypercholesterolaemia with statin treatment. ${ }^{2}$

Familial hypercholesterolaemia is an autosomal dominant disorder, inherited on average by one in two children of an affected parent. The prevalence in the United Kingdom is about 1:500, but at least three quarters of cases remain undiagnosed. ${ }^{3}$ It is usually caused by mutations in the gene for the low density lipoprotein (LDL) receptor that result in accumulation of plasma cholesterol and substantially increased coronary mortality. Without effective treatment the cumulative risk of a coronary event is at least $50 \%$ in men and 30\% in women by the age of 60 years. ${ }^{4}$ With statin treatment, however, the standardised mortality ratio for coronary heart disease for such patients aged
20-59 years has more than halved over the past decade. $^{2}$

\section{Participants, methods, and results}

We conducted a survey of 41 life assurance companies in $1990^{5}$ and repeated it in 2002 by sending the same questionnaire to 26 companies still underwriting term life assurance. They were asked to assess a fictional proposal for a 20 year policy (paying benefit only on death) by applying an excess mortality rating defined as the percentage increase over the assumed rate of mortality. In the follow up survey companies were asked to assess the rating before and after statin treatment. The applicant was a normotensive $(120 / 80 \mathrm{~mm}$ $\mathrm{Hg}$ ), non-smoking, 30 year old man taking no medication, with a body mass index of $22.1 \mathrm{~kg} / \mathrm{m}^{2}$ and a normal resting electrocardiogram, whose father had had a non-fatal myocardial infarction aged 45 years. He had no other family history of heart disease, other medical history of note, or tendon xanthomata on examination. The results of the lipid profile $(\mathrm{mmol} / \mathrm{l})$ were total cholesterol 11.4, high density lipoprotein (HDL) cholesterol 1.7, triglycerides 1.3, and calculated LDL cholesterol 9.1; and the presumptive diagnosis was familial hypercholesterolaemia. On treatment with atorvastatin $80 \mathrm{mg}$ daily his total cholesterol concentration was $6.2 \mathrm{mmol} / \mathrm{l}$ (compared with $10.7 \mathrm{mmol} / \mathrm{l}$ on cholestyramine prescribed in 1990).

The figure shows the excess mortality ratings applied. Because two companies would assess proposals only from patients receiving statin treatment statistical comparisons were restricted to 24 companies. The 